\title{
PUBLISHING
}

\section{A tribute to a commitment to the Pacific region}

Commentary: In more ways than one, the political events in Fiji since that fateful day have had a profound effect on political journalism in the Pacific. Many contemporaries, who worked as journalists in Fiji at the time, paid dearly for defending the Fourth Estate. They were unified in their views and they vehemently defended the right to call things as they saw them - a spade was a spade, black was black and white was white.

Keywords: censorship, coups, Fiji, ethics, Fourth Estate, political journalism

WALTER FRASER

AUT Office of Pacific Advancement

- ARLIER in 2014, I was listening to a local radio station as I was stuck in traffic, as one normally is in Auckland, when the radio announcer said that the 40th Anniversary special edition of John Lennon's Imagine had just been released, and began to play it. As the song played, it triggered clear memories for me of a distinct moment in history, as though it was only yesterday.

I am sure that we all have such moments. For some, it might have been when John F. Kennedy was assassinated on 22 November 1963; for others it might have been when people landed on the moon, or when the Berlin Wall came down.

Most of us will remember where we were when the World Trade Centre was attacked in September 2011. For Professor Robie and some others here, it might have been the moment they held the very first issue of the Pacific Journalism Review in their hands.

For me, John Lennon's Imagine always takes me back to 14 May 1987-I was driving my white Suzuki Vitara up Moto'otua Road in Samoa and it was a little after 12 noon. An old friend of mine, 'Ulafala Aiavao, who was a journalist at the time for Radio 2AP in Samoa, had just interrupted the airwaves with news that there had been a military coup in Suva.

I distinctly remember pulling off to the side of the road next to Apia's Anglican Church in utter shock. I still clearly remember Fala's tone- he sounded like he was reading a funeral notice. When he finished, he played Lennon's Imagine and dedicated it to the people of Fiji. 
POLITICAL JOURNALISM IN THE ASIA-PACIFIC

I had heard and hummed that song hundreds of times before, but never really paid attention to the lyrics as I did that hot sunny afternoon in Apia.

In more ways than one, the political events in Fiji since that fateful day have had a profound effect on political journalism in the Pacific. Many of my contemporaries who worked as journalists in Fiji at the time, paid dearly for defending the Fourth Estate. They were unified in their views and they vehemently defended the right to call things as they saw them: a spade was a spade, black was black, and white was white.

Similarly, the political upheaval of 2000 with George Speight found a new generation of journalists, many of whom were Professor Robie's journalism students at the University of the South Pacific, again risking their lives to ensure that we all received news.

Again, unified in reporting the events as they saw them—striving to be impartial, as it were. By this time, I was working here in Auckland and I remember logging in keenly to read the regular internet updates from these students on their Pacific Journalism Online website at USP. Unlike in 1987, this time we were not limited to print or broadcasts. We also had the internet.

\section{Digital platforms}

Not long after, I returned to Fiji to work as Registrar for the University of the South Pacific. I was there in 2006, when the Voreqe Bainimarama coup occurred. Unlike previous upheavals, this time the medium for the disbursement of information was vastly different. We now had a much wider range of digital platforms - blog sites, Facebook, Twitter and the like - through which a myriad of views could be expressed easily and speedily and with a relative lack of censorship and ethical or professional standards.

In his address, delivered as the Andrew Olle 2010 Lecture, British journalist and editor of The Guardian, Alan Rusbridger, said:

Virtually every adult over the age of 30 grew up with the idea that the Fourth Estate consisted of just two parts - press and broadcasting. Each was owned, financed and regulated in different ways and each gave rise to different ideas of what journalism was.

There was much to cherish in the balances and tensions inherent in this duopoly. A reader or viewer could measure the message of one medium against the other. There was the tent peg of attempted impartiality by which to measure the Wild West of the printed word.

But now there's a new kid on the block. You could even argue there are two new kids on the block - the original world wide web (essentially another form of transmission) and web 2.0, the advent and rapid maturing of so-called social, or open media. No one owns the digital space and it is barely regulated. It brings with it an entirely new idea of what journalism is - indeed, for some, it calls into question whether there is any such distinct thing as 'journalism'.

This double revolution within just over 20 years is having a dramatic effect on the accepted norms and categorisations of information. We are seeing the splintering of the Fourth Estate. (Rusbridger, 2010)

16 PACIFIC JOURNALISM REVIEW 21(1) 2015 
In terms of the Pacific, in my view, this 'splintering' has also been manifested in the numerous rival regional media groupings that have emerged in the recent past and the tensions that frequently call into question their own ability to remain impartial and ethical.

\section{Successful positioning}

This backdrop, despite the bias of my Fijian lens, resonates well with any tribute that one might pay to the Pacific Journalism Review. Over the last 20 years, the journal has successfully positioned itself as a quality publication, where those committed to the development and advancement of the Pacific Islands region can find a platform to debate Pacific media issues.

I first met Professor Robie when I went to USP at the beginning of 2001 and attended an event to celebrate the success at the Ossie Awards of those very students who reported on the 2000 Fiji coup. Now I find myself at an event, where we were not only paying tribute to 20 years of publishing Pacific Journalism Review, but we are also celebrating yet more of his students winning Ossie Awards - this time for their coverage of Fiji's democratic elections.

There is fortuitous and poetic serendipity and synergy in the timing of all of this, and the threads of issues and topics that have been interwoven throughout the programme of this conference certainly reflect the rich and colourful tapestry that is $P J R$. I warmly congratulate those involved with PJR on your 20th anniversary.

Walter Fraser is Head of Pacific Advancement at Auckland University of Technology. This commentary was drawn from an opening speech he delivered at the PJR2014'Political journalism conference in the Asia-Pacific' on 27-29 November 2014.

\section{Reference}

Rusbridger, A. (2010). 2010 Andrew Olle Media Lecture: The splintering of the fourth estate. Australian Broadcasting Corporation, Sydney. Retrieved on March 16, 2015, from http://www. abc.net.au/local/stories/2010/11/19/3071359.htm 